\title{
Teaching languages in multicultural surroundings: New tendencies
}

\author{
Maria YELENEVSKAYA ${ }^{\mathbf{1}}$ and Ekaterina PROTASSOVA ${ }^{\mathbf{2}}$ \\ ${ }^{1}$ Technion-Israel Institute of Technology \\ Haifa, Israel \\ ${ }^{2}$ University of Helsinki \\ Helsinki, Finland
}

\begin{abstract}
The purpose of this article is to help language teachers at all levels of education to understand in depth problems posed by linguistic superdiversity. Based on the study of scholarly literature, documents of educational bodies and the authors' experience in language teaching in different countries, the article answers the question of how the teaching of world languages such as English and Russian is changing due to the recognition that their functions and status differ in various countries. We explore why, despite gradual changes in curricula, there is still pervasiveness of pedagogies attempting to achieve a 'perfect' command of the studied languages, without considering students' needs and language repertoires, the local sociolinguistic situation and labor market requirements. We focus on methods of teaching English and Russian, taking into account various aspects of language ideologies related to mono- and pluricentricity. To show the dependence of language teaching on the socio-cultural situation, we apply the concept of Critical Language Awareness covering aspects of language variation and changes in attitudes to normativity, prescriptivism and regional language varieties. We also show that innovative pedagogies put new demands on teachers requiring that they have to adjust to new teaching formats, acquire skills of using educational technologies and teaching diverse student populations. The focus of the review on teaching English and Russian proves that despite different histories of their pedagogies, the interplay of language, ethnicity, identity, culture and education systems is significant for both, and without taking all these elements into account, the goal of educating effective multilinguals is elusive.
\end{abstract}

Key words: international language, lingua franca, normativism, prescriptivism, Critical Language Awareness, variability

\section{For citation:}

Yelenevskaya, Maria \& Ekaterina Protassova. 2021. Teaching languages in multicultural surroundings: New tendencies. Russian Journal of Linguistics 25 (2). 546-568. DOI: https://doi.org/10.22363/2687-0088-2021-25-2-546-568 


\title{
Преподавание языков в многоязычном окружении: новые тенденции
}

\author{
Мария ЕЛЕНЕВСКАЯ ${ }^{1}$, Екатерина ПРОТАСОВА ${ }^{2}$ \\ ${ }^{1}$ Технион - Израильский технологический институт \\ Хайфа, Израиль \\ ${ }^{2}$ Хельсинский университет \\ Хельсинки, Финляндия
}

\begin{abstract}
Аннотация
Цель настоящей статьи - помочь преподавателям языка на всех уровнях образования глубже осознать, с какими проблемами они сталкиваются в условиях “языкового сверхразнообразия” (linguistic superdiversity). Основываясь на исследовании научной литературы, документов органов управления образованием и опыте авторов по преподаванию языков в разных странах, статья отвечает на вопрос о том, как меняется преподавание таких мировых языков, как английский и русский, в связи с признанием того, что их функции и статус в разных странах различны. Мы исследуем, почему, несмотря на постепенные изменения в учебных планах, все еще распространены педагогические методы, направленные на достижение «совершенного» владения изучаемыми языками, при этом не учитываются ни потребности студентов и их языковой репертуар, ни местная социолингвистическая ситуация и требования рынка труда. Основное внимание уделяется методике преподавания английского и русского языков с учетом различных аспектов языковых идеологий, связанных с моно- и плюрицентричностью. Чтобы продемонстрировать зависимость обучения языку от социокультурной ситуации, мы опираемся на концепцию критического языкового сознания (Critical Language Awareness), охватывающую аспекты языковой вариативности и изменения отношения к нормативности, прескриптивизму и региональным языковым разновидностям. Мы также показываем, что инновационная педагогика предъявляет новые требования к учителям, ожидает от них адаптации к новым форматам обучения, освоения образовательных технологий и приобретения навыков обучения разнообразного состава студентов. Особое внимание в обзоре уделяется преподаванию английского и русского языков. Доказывается, что, несмотря на различия в педагогических традициях, для обеих значимо взаимодействие языка, этничности, идентичности, культуры и системы образования. Без учета всех этих элементов комплексная цель воспитания успешных мультилингвов недостижима.
\end{abstract}

Ключевые слова: международный язык, lingua franca, нормативность, прескриптивизм, критическое языковое сознание, вариативность

\section{Для цитирования:}

Yelenevskaya M., Protassova E. Teaching languages in multicultural surroundings: New tendencies. Russian Journal of Linguistics. 2021. Vol. 25. № 2. P. 546-568. DOI: https://doi.org/10.22363/2687-0088-2021-25-2-546-568

\section{Introduction: Teaching languages with a changing status}

The necessity to write this article was dictated by major changes in the role language plays in the globalized world and its economy. Intensification of migration, technological advances promoting fast exchange of information, and transnational connections in business and private life are among the factors that make effective language learning an urgent issue in contemporary life. Like in other 
fields, language pedagogies require fast response to societal needs, but are not always able to keep up the required pace.

Relying on our own long-term experience in teaching English and Russian to various audiences in different countries we aim to alert academic linguists and practitioners in educational systems to the interconnectedness of social changes and growing multilingualism in populations with the need for flexible language pedagogies. While in the past Russian teaching was almost exclusively oriented to the Moscow norm, in the post-Soviet decades Russian speakers have formed numerous vibrant but dispersed speech communities influenced by new contact languages. As a result, new regional varieties are evolving and cannot be ignored in teaching practices. Therefore, focusing on teaching English and Russian, we will try to show what Russian-speaking societies can learn from the Anglophone world in the sphere of pluricentric language usage, maintenance and teaching. We will continue our discussion focusing on standard and/or dominant language ideologies and their consequences for the language teaching and learning.

Material for the article is drawn from multiple scholarly publications and documents issued by various educational committees (see, e.g., Haß, Frank. 2016, Leppänen et al. 2007, Levi et al., 2019). We studied coursebooks for different student populations and different levels of linguistic and communicative competences, and we analyzed multiple online resources. We reviewed our own and our colleagues' lesson protocols and conducted discussions with teachers, parents and students. A variety of resources enabled us to look at the language teaching from different perspectives. We applied content analysis to single out themes relevant to our aims and we employed critical discourse analysis to place language pedagogies into the socio-cultural context. In addition, we used the method of included observation, an essential tool in ethnographic studies.

The main questions we intend to answer in this review are as follows:

- How does the superdiversity of learners and teachers affect languageteaching processes?

- How should language pedagogies of pluricentric languages differ from those of monocentric languages?

- Are international language pedagogies transferrable?

- What knowledge and skills are prerequisites for language teachers today?

- What are the arguments for teaching Russian outside the nation as a pluricentric and international language?

\section{Language pedagogies in the context of socio-cultural changes}

There is a growing body of research into English as an International Language (EIL), and there is emergent literature on Russian as a pluricentric and international language, which in various situations can be used as a lingua franca. These three terms are in no way interchangeable since they denote different, although partially overlapping phenomena. A pluricentric language develops varieties in different countries and regions under the influence of contact languages. A global/world/ 
international language is spoken in various geographic areas, and so it also has multiple varieties. As a rule, global languages are big with millions of native and non-native speakers. They are accepted for communication in various international organizations and have a large body of literature published conventionally and electronically. A lingua franca meets communication needs of various speech communities and for this reason it is often simplified by the speakers who may use it in a limited number of domains and with multiple and different mistakes which, however, do not hamper communication. International languages are most popular in language education, as they enable speakers to use them in a variety of areas, in multiple functions and for a multitude of purposes. Teaching a variative language entails development of multiple approaches taking into account local traditions, vernaculars, various degrees of preliminarily attained competences, educational background and professional ideologies of pedagogical staff, available equipment, and other factors (Sharifian 2009, Marlina and Giri 2014). These changes in approaches require significant adaptation and transformation on the part of educators, including building upon students' interests, balanced use of other languages and literacies, without shying away from translanguaging methods (García et al. 2011, Sayer 2013). The linguistic and national identity, flexibility and professional competence of a teacher depend on the context of language acquisition, general education, and experience in teaching languages. Therefore, the language is differently transmitted to the students, and almost always, a teacher has his/her own speech habits and mannerisms, as well as values and beliefs (Zheng 2017). The discourse of identities shapes the learning of a language because it is impregnated with sociolinguistic variables, such factors as geographic location of the school, ethnic belonging of the teachers and students, types of dwellings found in the area, language spoken in the communities, overall attitudes to multilingualism, and others (Archakis and Tsakona 2012).

Teaching a language can hardly succeed without teaching culture, but what culture should one teach first - one's own or alien, the global or the local? Who has the right to represent the culture connected to the language - only those who speak this language perfectly or also those who want to acquire and expand their cultural capital? The situation of the world languages spoken in multiple countries differs from that of the languages spoken just in one country or by small groups of people (Pennycook 1994, Byram 2012, Farrell 2019). Educators are increasingly inclined to teach their students to use English and Russian as international languages that can function as a lingua franca in various situations. Clearly, this is a new pedagogical target (Baker 2015, Bayyurt and Akcan 2015, Tatsioka et al. 2018), and it is often accompanied by purposeful simplification of the language material taught to speed up its acquisition and use for communicative purposes (Templer 2012).

Multidimensional and multilateral curricula, application of new technologies and innovative forms of interaction, linguistic diversity and superdiversity, as well as changes in the status of languages have become a reality of our time. Languages are seldom isolated, and today they interact and develop in contact as never before. 
The classic four-skill model has been replaced by integrated multi-skill instruction addressing a range of skills requisite in oral and written communication simultaneously. Only situationally relevant pedagogies which take into account the needs and linguistic repertoire of the students motivate the learner (Hinkel 2006, Taylor et al. 2017). Yet, practitioners are not always ready to embrace new didactics, but prefer to go along the well-trodden path. Moreover, in the schools of economically weak countries new coursebooks are often unavailable, and the teachers have to make do with what they have been using for decades.

On the whole, the distance between the teacher and the learner has decreased, while the degree of the learners' engagement has grown. Students have become more active in determining their goals of language learning. The stakeholders should be aware of these changes and introduce new skill and proficiency measurements while revising curricula, setting the goals of learning, choosing the format of learning (face-to-face, blended or online only), providing guidelines for writing teaching materials and deciding on forms of assessment. Today, in the same language classroom, there are often first, second, foreign, minority, international, and heritage language learners (Beaudrie et al. 2019, 2021, Bergmann, Böhmer 2020), which requires flexibility of approaches.

The Common European Framework of Reference for Languages (CEFR) has become an international standard for language ability, making it easier to exchange teaching and testing materials and engage in joint projects. In 2020, an updated version was published (Council of Europe 2020). Its authors sought to create a continuum of progression from schools to higher education and build a bridge between local and global contexts of languages worldwide. At all levels of skills the CEFR addresses ethnic and linguistic superdiversity of language learning and various modes and media of communication. While in the past the emphasis in language teaching in many countries was on receptive skills, the CEFR promotes the development of a combination of both receptive and productive skills as inseparable components of communication. Moreover, it sets a goal of ensuring equal opportunities and enhancing life chances for learners from different cultures, regions, and sectors.

Another recent trend in language pedagogies is inclusiveness. Language instructors and researchers are investigating and experimenting with how to improve teaching students with learning disabilities (LD) and special educational needs. These students are a heterogeneous and expanding group, and their specific difficulties vary. They may experience greater difficulty than other students with decoding new vocabulary, visual and oral processing, retaining new information, and/or organizing ideas (García and Tyler 2010). One of the current goals is to reduce segregation of such students and include them in regular educational settings, providing them with additional support services that would facilitate their further integration into society and help them find employment. Research from different countries shows that these learners having specific difficulties in their native language will experience similar, and often more severe, difficulties with the 
acquisition of additional languages and literacy skills in particular (see e.g., Kormos and Smith 2012, Russak 2016). Clearly, in order to help these students, diagnostics and special programs catering to their individual problems are required. Notably, linguistic superdiversity in current educational settings may increase errors in measuring the degree of LD and reduce the reliability of students' difficulty assessments (Chu and Flores 2011).

Special training and retraining courses are needed to help teachers give adequate assistance to LD and very weak students. One of the problems with these students participating in classes together with their peers is that in big classes the teacher seldom has an opportunity to cater to their special needs. This is possible to do during small-group or individual tutorials, recapitulating important points, jointly working out learning strategies appropriate for each student and encouraging LD learners to self-reflection about the tools and methods that are effective. It is beneficial for these students to combine face-to-face teaching and tutorials with digitized materials enabling students to work at their own pace (Tal and Yelenevskaya 2012). These students need accommodation in tests, and not all types of assessment are suitable for them. Yet, such technologies as text-to-speech software, the use of subtitles in videos, changing the speed of speech in audio- and video-recordings, enlarging fonts in texts, choosing colors and the format of paper and other types of accommodation may facilitate learning for LD students and help them find ways to continue perfecting the target language autonomously.

\section{Critical Language Awareness and the teaching of languages}

The theoretical frame for our study is formed by the theories of bilingual education, functioning of different languages in a society, language pedagogies, second language teaching, and language policy. All of these come together under the umbrella term of 'Critical Language Awareness' (CLA) (Lambert et al. 2000). The notion of CLA was conceived of by Norman Fairclough (1992). Later, together with some other scholars (e.g., Wallace 1999, Farías 2005) he elaborated it, claiming that CLA should be included in everyday language teaching practices. Awareness of what is going on with the use of language, its power and manipulative potential are vitally important for language teachers and learners. They should also develop a critical view of prejudices and stereotypes concerning whose language is 'appropriate' and whose is not (Maunter 2010, Simpson et al. 2019). Decisions about what and how to teach have a long history, and they must be explained to the students, so that the learning process is fully conscious. It is also useful to introduce learners to the basics of critical discourse analysis, so that they understand the role of language in society. Without such 'vaccine' nobody can be immune to the myths of natural dominance of one variety above others. This is the most sensitive part of language functioning because it is connected with the personality of the speakers.

There is a growing realization among educators that world languages should be taught differently from other languages. Some global languages serve for intercultural communication, which requires considerable additional knowledge 
from the students who have to process verbal, audio and visual information in the conventional and digital form and attain their goals applying their interactional and transactional competence (Houghton et al. 2013). Nowadays, the process of language learning should include acquisition of symbolic and translingual competences, as well as soft skills, such as regulation of prosody, body language and distance in communication. CLA can be trained with the help of teachers. They can share awareness of standardized and dialectal varieties with their students, explain how code-switching functions and when it is inappropriate. They can discuss which language versions give speakers privileges and which marginalize them (Carpenter et al. 2015, Godley et al. 2015, Shi and Rolstad 2020). Most importantly, they can motivate students to think about the role of language in their own life and in the life of their community. Development of CLA may be implemented with the help of different projects in which children and adult students collaborate with their peers in their own and other countries (Straaijer 2014, Karagiannaki and Stamou 2018, Scott-Monkhouse et al. 2021).

Language learning is facilitated when learners build on their previously acquired language/s and world knowledge. In the past, some countries exceedingly relied on translation, others chose to use exclusively the target language in the classroom. Today, educators are trying to find a compromise resorting to their students' L1 judiciously when it can promote learning of a target language. Pointing to language universals and alerting students to the problems of language interference may help develop language awareness already in the early stages of learning.

\section{Language teachers: New professional challenges}

Education departments in various countries issue documents addressing language teachers' competences and provide guidelines for developing and evaluating them. Notably, in the past, the main criterion for being a language teacher was proficiency in the language (see, e.g., Butler 2007, Richards 2011). This point of view was particularly dominant in the teaching of English. So, it was enough to be a native speaker to be employed not only at school but also at the university. Holding degrees in fields as different as biology, sociology or engineering, these novices in pedagogy had little idea of educational psychology, didactics, or language-teaching methodologies. They had to learn on the job, relying on trial-and-error methods (Moussu 2018). New policies of teacher training set as their main goals support and guide English language teachers in their professional growth as they develop their professional and soft skills and pedagogical knowledge. Research-based principles should be used in teacher training and professional development programs. They can also serve as a complement to the tools for teacher evaluation.

The current movement toward democratization, diversity and variability requires of educators to delve deeply into such issues as multilingualism as it varies by the very contexts in which people function at any given point in time. Language 
teaching ideologies are gradually shifting from monoglossic to heteroglossic models. Innovative teachers try not to ignore that many of their learners are emergent bi- and multilinguals and look for ways to mobilize their knowledge of other languages in facilitating acquisition of a new language. Theorists supporting these ideologies advocate differentiating between the types of support that are required by emergent bi- and multilinguals at different levels of new-language proficiency (Huffeisen and Jessner 2018). As mentioned earlier, such multilingual practices as translanguaging should not be avoided in education. Just the opposite, learning tasks should be designed in such a way that bi- and multilinguals can use their different language resources in mastering a new language. Moreover, translanguaging should not be conceptualized as just a form of scaffolding, rather it should be viewed as a legitimate discursive practice of bilingual communities. Students should be exposed to bilingual writing and helped to explore how to make choices to best express themselves using all their linguistic resources (Flores and Schissel 2014: 474, Van Viegen 2016).

An additional challenge for new and even experienced teachers is mastering fast developing educational technologies. It is no secret that digital literacies of the students often surpass those of the teachers. Learning a language in the digital age goes beyond learning grammar, acquiring vocabulary and becoming pragmatically competent in the target language. It also involves learning how to use various modes and media of communication. The new communicative competences needed in L1 and L2 (and sometimes in L3, L4, etc.) is the ability to search for and critically evaluate large quantities of information in online databases, to construct meaningful reading paths through hypertext documents, to comment on the online writing of others in culturally appropriate ways and to construct knowledge collaboratively with peers (Jones 2014).

Teacher-training programs include courses enabling trainees to perfect the mastery of the language they are going to teach, linguistic disciplines, such as phonology, lexicology, syntax, and discourse analysis, as well as history of pedagogical theories and psychology. Trainees take courses in such areas as curriculum planning, reflective teaching, types of assessment, classroom management, and others. An increasingly popular format is international collaborative projects in which teacher trainees in different countries work on joint projects and present them to their fellow-students and professors at teleconferences (Lawrence and Spector-Cohen 2018). Such collaboration has important social implications as it contributes to the establishment and solidification of transnational ties. In addition, it helps educators in partner countries to exchange their know-how and jointly work on innovating didactic methods.

During the lockdowns due to the COVID-19 pandemic, many schools worldwide went online. This gave a significant push to posting language teaching materials for various levels. They include video lessons, PPT presentations, charts, games, etc. Teachers can use them freely and are encouraged to give credit to their colleagues who uploaded them. Some of these presentations are accompanied by 
voice and subtitles (see, e.g., multimedia materials of "English from Home" on the website of the Ministry of Education in Israel (sites.google.com/view/ englishfromhome/home, retrieved 20 April 2021). The site is regularly updated, and all the files are accessible and free.

Moreover, some providers of content uploaded guidelines, materials and suggestions for activities that could be used by parents wishing to support their children's studies at home. A case in point is a site of the British Council (learnenglishkids.britishcouncil.org, retrieved 20 April 2021). Materials on the site are free, and the parents are encouraged to use them without inhibitions even if they do not know English well, because instructions can be given in one's own language, and at the end of the activity the children can report about it in that language too.

New methods, platforms and ideas of distant teaching mushroomed and became topical. The situation emphasized the importance of home practices (storytelling and talk with children around these stories, not only in developing L1 but also in developing children's literacy skills as a whole. On the other hand, contact teaching developed into an expensive privilege not accessible to all. This sudden jump into the new world of teaching demands careful exploration and analysis which may be followed by a re-evaluation and revision of the previous attitudes and approaches.

\section{From foreign-language textbooks to course-management systems and pedagogical shareware}

When discussing materials used to teach international languages, many questions arise: who should write and compile course books? Where should they be printed, whose culture should be represented in them and how? (CurdtChristiansen et al. 2015). Students should be motivated to reflect on such issues and discuss their and other speakers' belonginess. Essential topics in these discussions are the specificity of customs and elements of material culture, cuisine, clothes, music, festive traditions, etc. The critical attitude should be directed towards oneself, one's in-group and others (Parks 2020).

Although there is an abundance of English and Russian teaching materials available today, every creative teacher knows that even a good coursebook is never enough and requires additions, updates and adjustments to the specific needs of the students. These come in the form of supplementary work sheets, CALL lessons, PowerPoint presentations and digitized tutorials and quizzes with answer key and sometimes with guided feedback. It is also beneficial to use authentic materials such as newspaper articles and interviews, internet posts, and audio and video-clips. In order to make the best of these materials, language teachers supply them with glossaries, vocabulary exercises and questions for discussion and essay writing.

A lot of eduware and ready-to-use kits are available on the market today to help language teachers, but even though some of them are very attractive, they are not customized and are not equally effective in different educational contexts. Many teachers try to use web materials in their classroom. This adds variety and can bring 
students closer to their interests and to authentic tasks they have to accomplish in their everyday digital practices. Yet, in order to truly enrich language learners, these authentic materials have to be seamlessly integrated into the course material, and meaningful tasks helping students process the information received and create their own are to be designed.

As mentioned earlier, many language teachers generously share their materials uploading them to the web for free access. Most of them are for beginners, lowintermediate and intermediate level students and are written for rote drill. Since some of them are supplied with feedback they are suitable for autonomous learning and can free classroom time for more creative tasks preparing students for communication in real-life settings. Advanced learners of Academic English can find tutorials providing tips as to how to write effective CVs and bio sketches, what to say and how to behave at a job interview and how to make oral presentations and visuals for them (see e.g., enago.com/academy/writing-a-good-academicbiography, work.chron.com/win-job-interview-12892.html, youtube.com/watch? $\mathrm{v}=\mathrm{fXVoT7VMCpM}$, retrieved 25 April 2021.

On the one hand, the demise of a traditional textbook has opened the door to teacher creativity and has enabled instructors to introduce changes and update their materials systematically; on the other hand, instant posting and dissemination of the new materials lack peer reviewing that safeguards high quality of materials.

\section{Teaching English: From a foreign to an international language}

Globalization of economy, growing access to electronic technologies and popularity of foreign travel contributed to the growing use of English in a variety of domains in the 1990s. Becoming the global language of communication for most of its learners, English is no longer just a foreign but first and foremost an international language with no particular national "owner". Despite these statements, in most educational institutions in non-English language countries it still has the status of a foreign language with teaching oriented to one of the two dominant varieties, British or American. Curricula usually emphasize the importance of the English language proficiency for all the speakers, but disregard that most countries are multilingual today, with many students learning English as a third or fourth language. Documents issued by educational authorities often state that the high priority of English teaching necessitates an increase in the number of teaching hours, well-trained teachers, a carefully planned curriculum, attractive and learning-rich materials, and the setting of high standards for assessment. However, these ambitious goals are not always implemented. Another problem is that in the same class there may be two or three different L1s, which complicates the work of the teacher as s/he cannot rely on the same background knowledge of the students (cf. Leppänen et al. 2007).

In many countries where English is not the native language, schoolchildren have to learn two foreign languages, and the first one is usually English. Even when a choice of several languages is offered as the first foreign language, English 
dominates. Learning begins in the $1^{\text {st }}$ to $4^{\text {th }}$ grade, with many schools trying to start as early as possible. English is taught in the primary school in Italy and Spain, France and Greece, Croatia and Poland, Estonia and Latvia, Israel and Turkey, Indonesia and Malaysia, South Korea and Vietnam, Singapore and Taiwan and many other countries (Uysal et al 2007, Spolsky and Moon 2012, Hopping 2014). Moreover, preschools offering English lessons or even English immersion are more valued but are usually expensive. Decisions when to start English instruction are often made locally and funded privately. They depend on the affluence of the schools and families whose children attend these schools (Chinh et al. 2014, Shohamy 2014: 280, Tsiplakides 2018). The level of the English language proficiency is often an indicator of class distinction and an essential prestige marker. Since English proficiency is a prerequisite for successful university studies, such policies perpetuate inequality discriminating against young people from socioeconomically weak groups, whose families cannot afford paying for an early start of English instruction or send their children to schools where English teaching is effective (see e.g., Berg et al. 2001, Jeon 2012, Tamim 2014). Inequality also persists in the minority and immigrant sectors, where most of the linguistic efforts of the students are made to master official languages of their country of residence. English is then their third or even fourth language. So being multilingual does not only fail to provide academic advantage to multilingual learners but on the contrary, may penalize them as they are not knowledgeable in the languages that society values most. At the same time, the learners' total linguistic repertoire is often ignored, therefore neither multilingual individuals, nor the society as a whole benefit from what could be valuable cultural capital (Kachru et al. 2006, Hall 2016, Kirkpatrik 2016, 2017, Proshina and Nelson 2020). The administrative bodies responsible for English teaching usually consult with academics while determining school policies related to English teaching and preparing documents and reports to be used as guidelines for teachers, school administrators, material and test writers, and teacher-trainers.

A problem specific for teaching polycentric languages, and English in particular, is that teaching materials, both intended for the international market and for local use, remain largely Anglocentric in their worldview and values. On the one hand, students do learn about the culture of the English-speaking countries or at least one of them from such course books; on the other hand, these cultures are not viewed analytically or critically. Moreover, course books are often oriented towards interaction with native speakers, but it is difficult to justify such an emphasis in materials intended for use in contexts where most English communication is between non-native speakers. Since some new curricula already proclaim English as a lingua franca/EIL, policy makers and educators have to make balanced decisions as to which varieties of English are relevant to their region (Matsuda 2012). To what extent should students be exposed to them and to what extent should they familiarize themselves with the standard varieties? These issues are complex from the pedagogical perspective and may be further complicated by 
the political agenda of each country (Hino 2020). Furthermore, it is not yet clear how these changes in the language ideologies might be implemented in course books (McGrath 2013: 7-11).

Despite rising demand for English proficiency in various domains, not all the teachers of English are competent enough to teach productive skills, in particular at advanced levels. In fact, some of the teachers in peripheral areas of some countries, or in schools located in areas largely populated by the socio-economically weak, have poor command of the language and can hardly converse in English. Moreover, the teaching materials do not balance information about countries where the target language is spoken with the information related to the students' life and world experience, thus reducing motivation (Shin et al. 2011). Neither are they related to the studies of the students' L1 and L2. Learning tasks should encourage students to use English as a means of gaining information in other subject areas, i.e., prepare them for CLIL. Yet, in practice there is little collaboration between Englishlanguage teachers and their colleagues teaching other subjects.

New English curricula developed in various countries set standards for four domains of language learning: social interaction, access to information, presentation of information and ideas, and appreciation of language, literature and culture. The latter one deserves special attention. Every educator knows that "digital natives" used to the hypertext prevalent on the internet often have trouble concentrating on linear reading. So, it is important for schoolchildren to be exposed to texts of different length and different genres, including descriptions, narratives, letters, recipes, advertisements, computer-mediated texts, etc. Moreover, children are expected to read extensively at home. However, schools are sometimes confronted with the problem familiar to all the educators today: pupils' book reports clearly remind one of summaries of the book content posted on the internet. In the best case, the pupils slightly paraphrase the downloaded summaries, but it is not uncommon to see entirely copy-pasted versions of other people's writing submitted as a pupil's own homework.

Updated English curricula presuppose that learners become acquainted with norms and behaviors in a variety of cultures and develop critical perspectives toward different cultural values and norms. In reality, however, even university students are not sufficiently equipped with knowledge about pragmalinguistic features of their own languages and English and differences between them (Kasper et al. 2010, Roever 2011). The linguistic hegemony of the official language goes hand in hand with cultural hegemony. Cultures of the other are often viewed with suspicion or patronizingly.

As a rule, a curriculum gives a list of words to be acquired at every stage of learning and lists grammar items to be covered. Although the main principle of teaching English grammar today is pointing to grammar phenomena in context, among the items to be taught, some are unlikely to be actively used or even encountered by schoolchildren, such as the Future Perfect Tense or the expression of wishes and regret in the subjunctive mood. By the end of high school studies, 
pupils are expected to be able to comprehend a wide variety of spoken and written texts and use them when creating their own texts. These expectations often fail to be realized. Approximately $90 \%$ of texts for reading is covered by around 3,000 word families ${ }^{1}$. To read independently, a person has to know 7,000-8,000 word families receptively (Laufer 2020). According to Nation (2006), $95 \%$ comprehension in novels is realistic with the knowledge of 4,000 word families, whereas in audition, with 3,000 word families. Yet, according to various sources testing real vocabulary size in L2 learners across countries and across languages comprises less than 2,000 word families, i.e., a lexical gap is huge and this may hamper further studies at the tertiary level (Hui 2004, Milton and Alexiou 2009, Schmitt and Schmitt 2014).

Immigrant-receiving countries deal with big groups of learners who are immigrant schoolchildren, students in the tertiary education system and adults who need oral and written English skills in order to find white-collar jobs. Moreover, immigrants seeking employment in high-tech, or academia sometimes require English more than the local languages. Immigrants from the former Soviet Union (FSU) often have lower English skills than their counterparts in their host societies. Those who received their education still in the Soviet times were poorly prepared to use English in their professional life. Those who studied in the post-Soviet times in big cities had much better access to language education; quite a few had an opportunity to travel and study abroad, enrolled in various international programs. This makes them more competitive on the job market.

\section{Russian as a global language: Between stability and diversification}

Until now, Russian was presented as a granite monument without cracks and scratches. Only recently have some scholars become engaged in discussions about variability of this language. Following the descriptive and prescriptive paradigms, some experts failed to see and accept the reality of language use. Social upheavals and economic changes, and an increase in migration and traveling led to numerous changes in the language use. Many of them were stigmatized by policy makers as bad and abnormal. Some educators, who had absorbed "the one language, one norm" ideology, blamed themselves for their inability to teach their students to speak correctly, fully adhering to the illusory norm characteristic of a hypothetical ideal native speaker. Paradoxically, political populism does not support the idea of democracy, admittance of any form of language employed by its speakers (Mustajoki et al. 2020, 2021). Although the realization that Russian is a 'pluricentric language' is gaining support among academic linguists, manifestations of its pluricentricity and their impact on the teaching and learning processes are still less frequently studied compared to such languages as English, French, German, and Spanish.

1 "A word family consists of a base word and all its derived and inflected forms that can be understood by a learner without having to learn each form separately" (Bauer and Nation 1993). 
When we want to look at ideologies of teaching language under specific political conditions, we must take into account that Russian is one of the world languages. Although, according to various sources, the number of L1 Russian speakers is dropping (Aref'ev 2020, Eberhard et al. 2021), its geography in the postSoviet period has expanded, and its features of a world language mentioned earlier remain solid.

We have chosen to talk about Russian language learning and teaching outside the country because of the presence of Russian in numerous countries as a heritage language, but also as a commodity (Heller and Duchêne 2012), and as an asset for many citizens both in Russia and outside her borders. The importance of the Russian language is growing in bilingual education. Clearly, Russian has become a commodity in many countries, and the ideological overtones in the policies of the Russian government in regard to Russian abroad are partially driven by this particular perception of the language, as a valuable instrument on the market of skills. 'Russian speakers' outside Russia are primarily multilingual. They are L1, L2 and heritage; many use the Russian variety as it evolved in their country of residence. Although in general it is better not to conflate 'speakers' and 'learners' because this can lead to incorrect categorization and numbers, they do meet in the educational process and interact with each other.

A few language professionals, still a rather narrow circle, are engaged in public and academic discussions on Russian normativism, yet there are no rank-and-file educators among them. Russian teachers in the diaspora often have to struggle for survival, and many of them do not have an opportunity to enroll in refresher courses or attend conferences to get abreast of the latest pedagogical innovations. Yet, realities of their classroom encourage them to innovate their teaching approaches, although often by trial-and-error method. Therefore, like in many other domains of diasporic activities, informal associations and websites created by Russianlanguage teachers working in the diaspora make an important contribution in sharing and disseminating professional know-how. As proof of the practitioners' interest in new approaches to teaching, the webinar "Russian as a foreign language in the era of the pandemic" organized by the St. Petersburg publishing house Zlatoust and held on April 29, 2021 gathered more than 1,500 attendees.

The ideologies behind the decisions of Russian families to emigrate vary and are not always thoroughly thought out. The outcomes of migration are suffered or enjoyed not only by adults, but also by children. In the post-Soviet space, new identities and new varieties of the Russian language are emerging and developing (Mlechko 2013, Mayorov 2015). In many countries of the world, Russian has been just introduced in education as a heritage or a foreign language (see e.g., Ryazanova-Clarke 2014, Nikunlassi and Protassova 2019, Noack 2021). This, together with new tendencies in language pedagogies, required elaboration of innovative approaches to language teaching, e.g., blended and online teaching that have received a huge boost due to the COVID-19 pandemic, collaborative projects in which children from different countries work together, as well as development 
of various didactic games (Guelfreich and Golubeva 2019, Protassova and Yelenevskaya 2020, Protassova et al. 2020). A new trend clearly visible in the diaspora is professionalization of parents. Mothers and grandmothers eager for the children to maintain Russian are creative in family language policies and share their experience (e.g., Madden 2014).

Entrusting children to bilingual preschools and schools or complementary Russian-language education centers, Russian parents enjoy the psychological comfort of speaking Russian, as they prefer to communicate in their own language. Parents in the diaspora believe that communication in Russian and the dominant language of the host country should be supported by teaching these languages. The majority value local languages and culture and understand their significance for integration. The Russian culture is sometimes appraised less than the Russian language; yet it is often graded as high or even higher than the welcoming culture, especially in the first years after immigration. Russian parents regard development of L2 as more important than of L1, but they still prefer the balance of languages. Conceivably, the reason for such an attitude is certainty of the Russian parents that Russian education is prestigious. Yet, some Russian parents make special efforts to read only or mostly in L2 to their children.

Some researchers insist on more emphasis on writing, others on extensive reading programs. The approach is still teacher- but not student-centered. When the context of teaching materials is denationalized to downplay the nationalism, in effect, it often alienates students. When it links to the local Russian speakers and their impact on the local society, it raises the self-esteem of the learners and enlightens their future as bilingual citizens of respective societies. Haim (2015; 2016) conducted a study of immigrant adolescents from the former Soviet Union to Israel to examine the transfer of literacy dimensions of academic proficiency across three languages (English, Hebrew and Russian) and made an important conclusion that the limited opportunities for immigrant children to study their heritage language throughout school years may curtail their development of academic proficiency both in L2 and in L3.

Clearly, designing the learning process in such a way as to ensure equal opportunities to learners from different cultures and socio-economic sectors is an ambitious project which requires a new set of course materials - a far cry from the coursebooks for the so-called native speakers (Lovtsevich and Gich 2018, Slavkov et al. 2021). The textbooks designed by L1 speakers, aiming at attainment of the L1 level of the language proficiency, based on Russia's realities are still in use at least partially and target the norm of Moscow as it is set in the majority of grammars and dictionaries. Textbooks published centrally in Russia often ignore issues of concern in other societies, have alternative historical perspectives or treat conflicts differently. This challenge confronts other countries and their experience of teaching Russian outside Russia. Similar processes occur worldwide. Yet, the corpus-based methods of language description, as well as statistically based text corpora and levels of lexical difficulties, videogames, and others adopt more suitable criteria for updating teaching resources. 
Other concerns are that the quality of instruction is inadequate. Classes are too big and meet for just a few hours per week; no educational technologies are used and teaching is conducted in a cultural vacuum. Moreover, many students in the first grades have not developed critical thinking, so they cannot transfer these mental skills to learning a L2. There is too much reliance on the native language during classes: the teachers are poorly prepared for instruction in Russian and had little practice in teaching productive language skills. Other issues are a lack of variety of teaching strategies and a boring repetitive format of the tasks. Teachers who are non-native Russian speakers have heavy accents and can hardly converse themselves. Therefore, they cannot teach speaking or pronunciation adequately. Teachers are low-paid, and the prestige of the school language teacher in society is not always high. Those who have a better proficiency often leave the profession for more decently paid jobs. Most teachers and instructors in secondary education are swamped with everyday teaching, test writing and grading. They are also expected to substitute for their colleagues when the latter are unable to show up for work, so, it is hard to imagine that teachers, particularly those who are in the middle or at the end of their careers, will be able to change their approaches to teaching overnight. Refresher courses help, and introduction to new theories is important, yet, as a rule, practitioners prefer concrete examples of how pedagogical principles and strategies are implemented to generalizations based on theory.

\section{Conclusion}

In this article we attempted to show that the current language curricula that are being implemented in schools differ from their predecessors in several important ways. Whereas previous curricula stressed language skills, the new curricula place greater emphasis on what should be achieved, along with how the language should be acquired (Timpe-Laughlin 2016). According to these innovations, teachers are encouraged to focus on domains, which are defined as "areas of language ability or knowledge," rather than on skills. Four major domains are taken into consideration in the current curricula: social interaction; access to information; presentation; and appreciation of literature, culture and language.

The interplay of ethnicity, identity, culture, education and language is evident and has long-term outcomes for all societies (Fishman and García 2010). Education models enabling effective language learning that does not hamper but facilitates studies of academic subjects are difficult to design and implement (Mohanty et al. 2009). We discussed the concept of the Critical Language Awareness helping curriculum management under new social configurations, economic demands and educational research findings.

The analysis confirmed that teachers should provide opportunities and motivate students to speak and write in a target language. Students should be encouraged to think about and discuss cultural differences reflected in the new and familiar languages in order to enhance understanding and linguistic sensitivities and develop socio-linguistic awareness. The critical approach presupposes continuous analysis of what is going on in the classroom, and what individual students' goals 
are. Teachers should carefully observe their students' performance in order to determine their strengths and weaknesses, and work to boost the former and repair the latter. It is also important to reflect on how the languages in the students' repertoire can interact with the languages being studied. Multimodality of functionoriented teaching boosts multiliteracies and translanguaging, interactional and transactional competence. It also contributes to developing metalinguistic knowledge and metacognitive awareness.

English is equally important for all learners because of its status as the international language of science, technology, commerce, and communications as well as for its usefulness in tourism and for international education and student exchange programs. Russian fulfils similar functions in the post-Soviet space, being important as the language of broader educational and professional opportunities. Migrants disseminate this language worldwide and use it in their transnational connections. Networks established by Russian speakers have a multiplicity of functions, ranging from mutual help in integration in host societies to starting up businesses and conducting joint research projects. Equally important is the role of the Russian language in establishing new and maintaining old friendships, organizing leisure activities for adults and children, and searching for romantic relations. Those who are proficient in Russian or want to maintain the language join numerous Russian-language online communities.

For teaching Russian outside the nation these functions, learner goals and communication forms are partly new and have not been exploited yet. Experience accumulated by Russian teachers in the diaspora is fertile ground for further research. In some schools, there are classes for heritage or native speakers, the former being a new category of learners in Russian-language pedagogies, acquiring the language in ways markedly different from those who learn it as a foreign language and, therefore, motivating teachers to search for new approaches. Schools in the diaspora also accept exceptionally good students, speakers of other languages. For all students learning Russian inevitably involves discovering another culture, or rather cultures. Language learners' comprehension of Russian-mediated cultures is influenced by their own culturally labeled worldviews. Symbolic competence acquired in the course of Russian studies enables students to benefit from the teacher's civilization and all the values represented by the culture/s behind the target language.

(C) Maria Yelenevskaya and Ekaterina Protassova, 2021
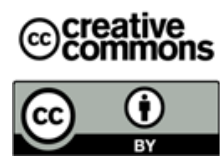

This work is licensed under a Creative Commons Attribution 4.0 International License https://creativecommons.org/licenses/by/4.0/

\section{REFERENCES}

Archakis, Argiris \& Villy Tsakona. 2012. The Narrative Construction of Identities in Critical Education. Basingstoke: Palgrave Macmillan. 
Aref'ev, Aleksandr L. (ed.). 2020. Indeks polozhenija russkogo jazyka v mire. Moscow: Pushkin State Russian Language Institute. URL: https://www.pushkin.institute/ news/index1.pdf. (accessed February 1, 2021).

Baker, Will. 2015. Culture and Identity through English as a Lingua Franca: Rethinking Concepts and Goals in Intercultural Communication. Boston: De Gruyter Mouton.

Bauer, Laurie \& Paul Nation. 1993. Word families. International Journal of Lexicography 6 (4). 253-279.

Bayyurt, Yasemin \& Sumru Akcan. 2015. Current Perspectives on Pedagogy for English as a Lingua Franca. Berlin: De Gruyter.

Beaudrie, Sara, Angelica Amezcua \& Sergio Loza. 2019. Critical language awareness for the heritage context: Development and validation of a measurement questionnaire. Language Testing 36 (4). 573-594.

Beaudrie, Sara, Angelica Amezcua \& Sergio Loza. 2021. Critical language awareness in the heritage language classroom: design, implementation, and evaluation of a curricular intervention. International Multilingual Research Journal 15 (1). 61-81.

Berg, Cathrine, Francis M. Hult \& Kendall A. King. 2001. Shaping the climate for language shift? English in Sweden's elite domains. World Englishes 20 (3). 305-319.

Bergmann, Anka \& Jule Böhmer. 2020. Perspektiven auf Heterogenität: Lehrpläne für Russisch als Fremdsprache und Russisch als Herkunftssprache. Jahrbuch des Dachverbands der deutschen Fremdsprachenverbände 8/9. 68-81.

Butler, Yuko G. 2007. Factors associated with the notion that native speakers are the ideal language teachers: An examination of elementary school teachers in Japan. JALT Journal 29 (1). 7-40.

Byram, Michael. 2012. Language awareness and (critical) cultural awareness - relationships, comparisons and contrasts. Language Awareness 21(1-2). 5-13.

Carpenter, Brian D., Mariana Achugar, Dan Walter \& Matt Earhart. 2015. Developing teachers' critical language awareness: A case study of guided participation. Linguistics and Education, 32. 82-97.

Chinh, Nguyen D., Le T. Linh, Tran H. Quynh \& Nguyen T. Ha. 2014. Inequality of access to English language learning in primary education in Vietnam: A case study. In Hongzhi Zhang, Philip Wing, Keung Chan, \& Christopher Boyle (eds.), Equality in Education: Fairness and Inclusion, 139-154). Rotterdam: Sense Publishers.

Chu, Szu-Yin \& Sobeida Flores. 2011. Assessment of English language learners with learning disabilities. The Clearing House: A Journal of Educational Strategies, Issues and Ideas 84 (6). 244-248.

Council of Europe. 2020. Common European Framework of Reference for Languages: Learning, teaching, assessment - Companion volume. Strasbourg: Council of Europe Publishing. coe.int/lang-cefr.

Curdt-Christiansen, Xiao Lan \& Csilla Weninger (eds.). 2015. Language, Ideology and Education: The Politics of Textbooks in Language Education. London: Routledge.

Eberhard, David M., Gary F. Simons \& Charles D. Fennig (eds.). 2021. Ethnologue: Languages of the World. $24^{\text {th }}$ ed. Dallas, TX: SIL International. Online version: ethnologue.com.

Fairclough, Norman. 1992. Critical Language Awareness. London: Longman.

Farrell, Angela. 2019. Corpus Perspectives on the Spoken Models Used by EFL Teachers. London, New York: Routledge.

Farías, Miguel. 2005. Critical language awareness in foreign language learning. Literatura y Linguistica 16. 211-222.

Fishman, Joshua A. \& Ofelia García (eds.). 2010. Handbook of Language and Ethnic Identity. $2^{\text {nd }}$ ed. Oxford: Oxford University Press.

Flores, Nelson \& Jamie L. Schissel. 2014. Dynamic bilingualism as the norm: Envisioning a heteroglossic approach to standards-based reform. TESOL Quarterly 48 (3). 454-479. 
García, Ofelia, Claire E. Sylvan \& Daria Witt. 2011. Pedagogies and practices in multilingual classrooms: Singularities in pluralities. The Modern Language Journal 95 (3). 385-400.

García, Shernaz B. \& Brenda-Jean Tyler. 2010. Meeting the needs of English language learners with learning disabilities in the general curriculum. Theory into Practice 49. 113-120.

Godley, Amanda J., Jeffrey Reaser \& Kaylan G. Moore. 2015. Pre-service English Language Arts teachers' development of Critical Language Awareness for teaching. Linguistics and Education 32. 41-54.

Guelfreich, Polina G. \& Anna V. Golubeva (eds.). 2019. Uchitelju russkoj zarubezhnoj shkoly [For the teacher of the Russian school abroad]. St. Petersburg: Zlatoust.

Haim, Orly. 2015. Investigating transfer of academic proficiency among trilingual immigrant students. The Modern Language Journal 99 (4). 696-717.

Haim, Orly. 2016. The effect of age of arrival on bilingual and trilingual academic proficiency. Israel Studies of Language and Society 8 (1-2). 202-237.

Hall, Graham (ed.). 2016. Routledge Handbook of English Language Teaching. London: Routledge.

Haß, Frank. 2016. Fachdidaktik Englisch. Tradition - Innovation - Praxis. Stuttgart: Klett.

Heller, Monica \& Alexandre Duchêne. 2012. Pride and profit: Changing discourses of language, capital and nation-state. In Alexandre Duchêne, \& Monica Heller (eds.), Language and Late Capitalism: Pride and Profit, 1-21. London: Routledge.

Hinkel, Eli. 2006. Current perspectives on teaching the four skills. TESOL Quarterly 4 (1), $109-131$.

Hino, Nobuyuki. 2020. English as a lingua franca from an applied linguistics perspective. In the context of Japan. Russian Journal of Linguistics 24 (3). 633-648. DOI: 10.22363/2687-0088-2020-24-3-633-648

Hopping, Claire. 2014. At what age should you start learning a second language? Language Trainers, languagetrainers.com/blog/2014/06/04/what-age-should-you-start-learning-asecond-language.

Houghton, Stephanie A., Yumiko Furumura, Mariia G. Lebed'ko \& Song Li. 2013. Critical Cultural Awareness: Managing Stereotypes through Intercultural (Language) Education. Newcastle upon Tyne: Cambridge Scholars Publishing.

Huffeisen, Britta \& Ulrike Jessner. 2019. The psycholinguistics of multiple language learning and teaching. In David Singleton, \& Larissa Aronin (eds.), Twelve Lectures on Multilingualism, 65-100. Bristol: Multilingual Matters.

Hui, Du. 2004. Reflections on vocabulary size of Chinese university students. International Education Journal 5 (4). 571-581.

Jeon, Mihyon. 2012. English immersion and educational inequality in South Korea. Journal of Multilingual and Multicultural Development 33 (4). 395-408.

Kachru, Braj B., Yamina Kachru \& Cecil L. Nelson (eds.). 2006. The Handbook of World Englishes. Oxford: Blackwell.

Karagiannaki, Evanthia \& Anastasia G. Stamou. 2018. Bringing critical discourse analysis into the classroom: A critical language awareness project on fairy tales for young school children. Language Awareness 27 (3). 222-242.

Kasper, Gabriele, Hanh thi Nguen, Dina Rudolf Yoshimi \& Jim K. Yoshioka (eds.). 2010. Pragmatics and Language Learning, 12. University of Hawaii at Mãnoa: Foreign Language Resource Center.

Kirkpatrick, Robert (ed.). 2016. English Language Education Policy in Asia. Cham: Springer. Kirkpatrick, Robert (ed.). 2017. English Language Education Policy in the Middle East and North Africa. Cham: Springer.

Kormos, Judit \& Anne Margaret Smith. 2012. Teaching Languages to Students with Specific Learning Differences. Bristol: Multilingual Matters. 
Lambert, Richard D., Elana Goldberg Shohamy \& A. Ronald Walton. 2000. Language Policy and Pedagogy: Essays in Honor of A. Ronald Walton. Philadelphia: Benjamins.

Lawrence, G. \& Elana Spector-Cohen. 2018. Examining international telecollaboration in language teacher education. In Dara Tafazoli, M. Elena Gomez-Parra, \& Cristina A. Huertas Abril (eds.), Cross-Cultural Perspectives on Technology-Enhanced Language Learning, 322-345. Hershey, PA: IGI Global.

Leppänen, Sirpa, Anne Pitkänen-Huhta, Tarja Nikula et al. 2007. National Survey on the English Language in Finland: Uses, Meanings and Attitudes. URL: https://www.varieng.helsinki.fi/series/volumes/05 (accessed March 1, 2021).

Laufer, Batia. 2020. Lexical Coverages, Inferencing Unknown Words and Reading Comprehension: How Are They Related? TESOL Quarterly. 54 (4). 1076-1085.

Levi, Tziona, Elana Spector-Cohen, Lisa Amdur, Orly Haim \& Beverley Topaz. 2019. Professional Framework for English Teachers 2020. Jerusalem: Ministry of Education, English Inspectorate. https://meyda.education.gov.il/files/Mazkirut_Pedagogit/English/ framework2020.pdf.

Lovtsevich, Galina \& Olga Gich. 2018. English and Russian terms "native speaker": Illusory equivalents. Russian Journal of Linguistics 22 (2). 436-447. DOI: https://doi.org/ 10.22363/2312-9182-2018-22-2-436-447

Madden, Elena. 2014. Russkojazychnye deti zarubezh'ja: Spravochnik mamy [Russianspeaking children of abroad: Mummy's directory]. Moscow: Russkij jazyk. Kursy.

Marlina, Roby \& Ram A. Giri (eds.). 2014. The Pedagogy of English as an International Language: Perspectives from Scholars, Teachers, and Students. Cham: Springer.

Matsuda, Aya (ed.). 2012. Principles and Practices of Teaching English as an International Language. Bristol: Multilingual Matters.

Maunter, Gerlinde. 2010. Language and the Market Society. Critical Reflections on Discourse and Dominance. New York: Routledge.

Mayorov, Aleksandr P. (ed.). 2013. Regional Versions of the National Language. Ulan-Ude: Buryat University.

McGrath, Ian. 2013. Teaching Materials and the Roles of EFL/ESL Teachers. Practice and Theory. London: Bloomsbury.

Milton, James \& Thomaï Alexiou. 2009. Vocabulary size and the Common European Framework of Reference for Languages. In Brian Richards, Michael H. Daller, David D. Malvern, Paul Meara, James Milton, \& Jeanine Treffers-Daller (eds.), Vocabulary Studies in First and Second-Language Acquisition: The Interface between Theory and Application, 194-211. New York: Palgrave Macmillan.

Mlechko, Tatiana P. 2013. Russian Language Personality of the Near Abroad. Chisinau: Slavonic University of the Republic of Moldova.

Mohanty, Ajit, Minati Panda, Robert Phillipson \& Tove Skutnabb-Kangas (eds.) 2009. Just Multilingual Education. New Delhi: Orient Longman.

Moussu, Lucie. 2018. Shortcomings of NESTs and NNESTs: Framing the issue. In John I. Liontas (ed.), The TESOL Encyclopedia of English Language Teaching. John Wiley's \& Sons. DOI:10.1002/9781118784235.eelt0044.

Mustajoki, Arto, Ekaterina Protassova \& Maria Yelenevskaya (eds.). 2020. The Soft Power of the Russian Language: Pluricentricity, Potitics and Policies. London: Routledge.

Mustajoki, Arto, Ekaterina Protassova \& Maria Yelenevskaya. 2021. Centrifugal and centripetal forces driving Russian language norms. Quaestio Rossica, to appear.

Nation, I. S. Paul (2006). How large a vocabulary is needed for reading and listening? Canadian Modern Language Review 63, 59-82.

Nikunlassi, Ahti \& Ekaterina Protassova (eds.). 2019. Russian Language in the Multilingual World. Helsinki: University of Helsinki. 
Noack, Christian (ed.). 2021. Politics of the Russian Language Beyond Russia. Edinburgh: Edinburgh University Press.

Parks, Elinor. 2020. The separation between language and content in Modern Language degrees: Implications for students' development of critical cultural awareness and criticality. Language and Intercultural Communication 20 (1). 22-36.

Pennycook, Alastair. 1994. The Cultural Politics of English as an International Language. London: Routledge.

Proshina, Zoya G. \& Cecil L. Nelson. 2020. Varieties of English and Kachru's expanding circle. Russian Journal of Linguistics. 24 (3). 523-550. DOI: https://doi.org/10.22363/ 2687-0088-2020-24-3-523-550

Protassova, Ekaterina \& Maria Yelenevskaya. 2020. Learning and teaching Russian as a pluricentric language. International Journal of Multilingual Education 1. 111-133.

Protassova, Ekaterina, Maria Yelenevskaya \& Johanna Virkkula. 2021. Old and new homes of the Russian language in Europe. RussianStudies.hu 2020, 243-270. DOI: https://doi.org/10.38210/RUSTUDH.2020.2.g.1

Reuver, Carsten. 2011. Testing of second language pragmatics: Past and future. Language Testing 28 (4). 463-481.

Richards, Jack C. 2011. Exploring teacher competence in language teaching. The Language Teacher 35 (4). 1-7.

Russak, Susie. 2016. Do inclusion practices for pupils with special education needs in the English as a foreign language class in Israel reflect inclusion laws and language policy requirements? International Journal of Inclusive Education 20 (11). 1188-1203.

Ryazanova-Clarke, Lara (ed.). 2014. The Russian Language Outside the Nation. Edinburgh: Edinburgh University Press.

Sayer, Peter. 2013. Translanguaging, TexMex, and bilingual pedagogy: Emergent bilinguals learning through the vernacular. TESOL Quarterly 47 (1). 63-88.

Scott-Monkhouse, Anila R., Michal Tal \& Maria Yelenevskaya. 2021. Integrating international teleconferences into EGAP courses: Preparing students for real-life situations. Language Learning in Higher Education (forthcoming)

Shohamy, Elana. 2014. The Weight of English in Global Perspective: The Role of English in Israel. Review of Research in Education 38. 273-289.

Sharifian, Farzad. 2009. English as an International Language: Perspectives and Pedagogical Issues. Bristol: Multilingual Matters.

Shi, Lijuan \& Kellie Rolstad. 2020. "A Good Start”: A New Approach to Gauging Preservice Teachers' Critical Language Awareness. Journal of Language, Identity \& Education. DOI: https://doi.org/10.1080/15348458.2020.1810045

Shin, Jeeyoung, Zohreh R. Eslami \& Wen-Chun Chen. 2011. Presentation of local and international culture in current international English-language teaching textbooks. Language, Culture and Curriculum 24 (3). 253-268.

Simpson, Paul, Andrea Mayr \& Simon Statham. 2019. Language and Power. Oxon: Routledge.

Slavkov, Nikolay, Sílvia M. Melo-Pfeifer \& Nadja Kerschhofer-Puhalo. 2021. The Changing Face of the "Native Speaker": Perspectives from Multilingualism and Globalization. Berlin: Mouton de Gruyter.

Schmitt, Norbert \& Diane Schmitt. 2014. A reassessment of frequency and vocabulary size in L2 vocabulary teaching. Language Teaching 47 (4). 1-3. DOI: https://doi.org/10.1017/ S0261444812000018

Spolsky, Bernard \& Young-in Moon (eds.). 2012. Primary School English-Language Education in Asia: From Policy to Practice. New York: Routledge.

Straaijer, Robin. 2014. Rules of engagement? Usage and normativism: Public discourse and critical language awareness. English Today 30 (2). 11-12. 
Taylor, Shelley K., Colette Despagne \& Farahnaz Faez. 2017. Teaching English as an International Language Pedagogy. In John I. Liontas (ed.). The TESOL Encyclopedia of English Language Teaching: Teaching Speaking and Pronunciation in TESOL. Hoboken, NJ: Wiley. DOI: https://doi.org/10.1002/9781118784235.eelt0660

Tal, Michal \& Maria Yelenevskaya. 2012. Computer-assisted language learning: Challenges in teaching multilingual and multicultural student populations. Procedia - Social and Behavioral Sciences 47. 263-268.

Tamim, Tayyaba. 2014. The politics of languages in education: issues of access, social participation and inequality in the multilingual context of Pakistan. British Educational Research Journal 40 (2). 280-299.

Tatsioka, Zoi, Barbara Seidlhofer, Nicos Sifakis \& Gibson Ferguson (eds.). 2018. Using English as a Lingua Franca in Education in Europe. Berlin: De Gruyter Mouton.

Templer, Bill. 2012. Creating a mini research center for simplified English and its pedagogy. International Journal of Innovation in English Language Teaching and Research $1(2) .201$.

Timpe-Laughlin, Veronika. 2016. Learning and development of second and foreign language pragmatics as a higher-order language skill: A brief overview of relevant theories. ETS Research Report Series. DOI: https://doi.org/10.1002/ets2.12124

Tsiplakides, Iakovos. 2018. Shadow education and social class inequalities in secondary education in Greece: The case of teaching English as a foreign language. International Journal of Sociology of Education 7 (1). 71-93. DOI: https://doi.org/10.17583/ rise. 2018.2987

Uysal, Hacer Hande, Lia Plakans \& Svetlana Dembovskaya. 2007. English Language Spread in Local Contexts: Turkey, Latvia and France. Current Issues in Language Planning 8 (2). 192-207.

Van Viegen Stille, Saskia, Robin Bethke, Jackie Bradley-Brown, Janet Giberson \& Gillian Hall. 2016. Broadening educational practice to include translanguaging: An outcome of educator inquiry into multilingual students' learning needs. The Canadian Modern Language Review 72 (4). 480-503.

Wallace, Catherine. 1999. Critical language awareness: Key principles for a course in critical reading. Language Awareness 8 (2). 98-110.

Zheng, Xuan. 2017. Translingual identity as pedagogy: International teaching assistants of English in college composition classrooms. The Modern Language Journal 101 (S1). 29-44.

\section{Article history:}

Received: 9 November 2020

Accepted: 15 February 2021

\section{История статьи:}

Дата поступления в редакцию: 9 ноября 2020

Дата принятия к печати: 15 февраля 2021

\section{Bionotes:}

Maria YELENEVSKAYA is Senior researcher in the Department of Humanities and Arts at the Technion-Israel Institute of Technology. Her research is devoted to the use of language in multilingual and multicultural settings, lingua-cultural aspects of immigration, computer-mediated communication, linguistic landscape of multicultural cities and linguacultural aspects of humor. She has authored and co-authored over 70 research papers, three scholarly monographs and five course books. She serves on the editorial board of three international scholarly journals and is a board member of Israel Association for the Study of Language and Society. 


\section{Contact information:}

Technion-Israel Institute of Technology

Haifa, Israel

e-mail: ymaria@technion.ac.il

ORCID: 0000-0001-7155-8755

Ekaterina PROTASSOVA holds Ph.D. in Philology and Hab. in Pedagogy. She is Adjunct Professor in Russian language at the University of Helsinki. She has authored and co-authored over 400 monographs, articles and book chapters, headed and participated in various international and national projects investigating language pedagogies, child and adult bilingualism, and the role of language and culture in immigrant integration. Her service to the profession includes editorial work for various journals and publishers and organization of seminars and conference panels.

\section{Contact information:}

University of Helsinki

Finland, Helsinki

e-mail: ekaterina.protassova@helsinki.fi

ORCID: 0000-0002-8271-4909

\section{Сведения об авторах:}

Мария ЕЛЕНЕВСКАЯ - старший научный сотрудник отдела гуманитарных наук Техниона - Израильского технологического института. Ее исследования посвящены использованию языка в многоязычных и мультикультурных условиях, лингвокультурным аспектам иммиграции, компьютерно-опосредованной коммуникации, языковому ландшафту мультикультурных городов и лингвокультурным аспектам юмора. Она является автором и соавтором более 70 научных работ, трех научных монографий и пяти учебных пособий. Она входит в редакционный совет трех международных научных журналов и является членом правления Израильской ассоциации по изучению языка и общества.

\section{Контактная информация:}

Technion-Israel Institute of Technology

Haifa, Israel

e-mail: ymaria@technion.ac.il

ORCID: 0000-0001-7155-8755

Екатерина ПРОТАСОВА - является адъюнкт-профессором русского языка в Хельсинкском университете, автором и соавтором более 400 публикаций - монографий, статей и книжных глав. Участвовала, в том числе и как руководитель, в различных международных и национальных проектах, посвященных изучению и преподаванию языков, двуязычию детей и взрослых, а также роли языка и культуры в интеграции иммигрантов. Она является членом редколлегий ряда журналов, организатором научных семинаров и конференций.

\section{Контактная информация:}

University of Helsinki

Finland, Helsinki

e-mail: ekaterina.protassova@helsinki.fi

ORCID: 0000-0002-8271-4909 